\title{
The Effect of House Prices on Household Consumption in Italy
}

\author{
R. Calcagno • E. Fornero • M. C. Rossi
}

Published online: 23 May 2009

(C) The Author(s) 2009. This article is published with open access at Springerlink.com

\begin{abstract}
This paper studies the effect of a change in real estate wealth on the consumption behaviour of Italian households, using the Bank of Italy's Survey of Household Income and Wealth dataset. We relate annual household consumption to capital gains in housing, controlling for characteristics such as age. In line with the empirical predictions of our model, we find the oldest households - which are less affected by the higher costs of future rent - to be the most affected by increases in real net housing wealth. Younger households, on the other hand, are not significantly affected in their consumption decisions by house price increases. We also take into account the fact that benefiting from capital gains is conditional on owning housing wealth and estimate the different impacts of house price changes on the savings behaviours of both homeowners and renters. Our estimates suggest that house price increases raise consumption not only for homeowners but also for renters.
\end{abstract}

Keywords Housing wealth · Marginal propensity of consumption on wealth · Life cycle consumption

JEL classification $\mathrm{D} 11 \cdot \mathrm{D} 12$

R. Calcagno ( $\square)$

VU University Amsterdam, Amsterdam, the Netherlands

e-mail: rcalcagno@feweb.vu.nl

E. Fornero

Facoltà di Economia, Dipartimento di Scienze Economiche e Finanziarie "G.Prato",

Università di Torino, Corso Unione Sovietica n. 218 bis, 10134 Torino, Italy

M. C. Rossi

Facoltà di Economia, University of Rome Tor Vergata, Via Columbia, 200133 Roma, Italy

E. Fornero - M. C. Rossi

CeRP, Via Real Collegio 30, 10024 Moncalieri (TO), Italy 


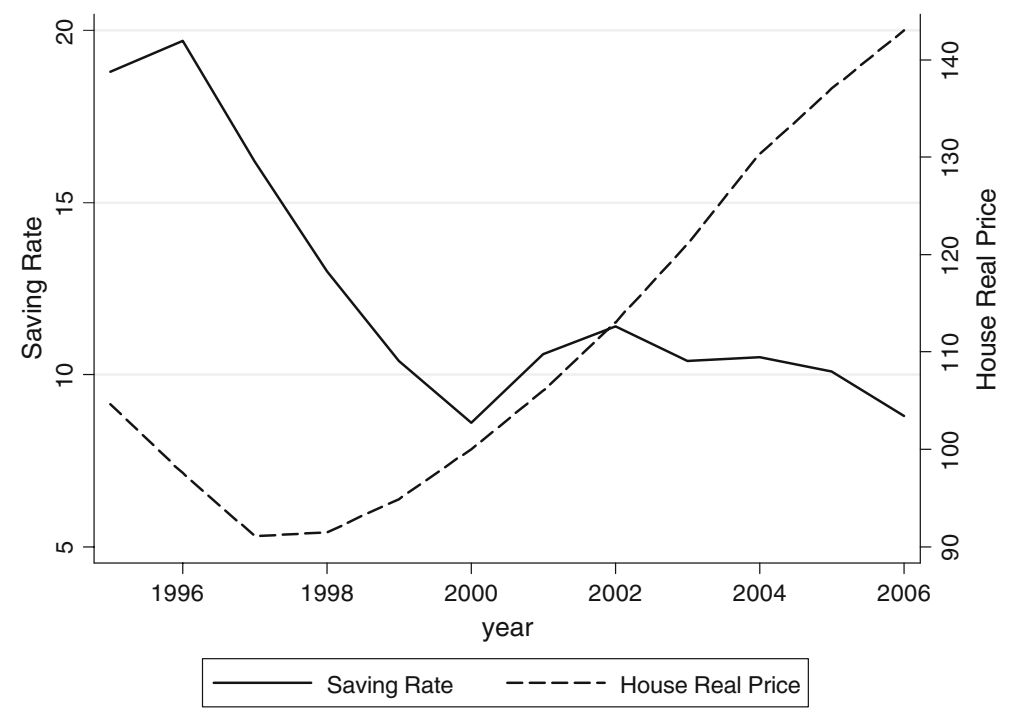

Fig. 1 Household saving rate and real housing price, Italy

\section{Introduction}

Household saving rates have been steadily declining in the United States, United Kingdom, and Canada. Italy, in contrast, does not seem to have followed this pattern (see Fig. 1). The standard explanation is that, unlike Americans, Italians did not cash in their substantial house valuations to raise their living standards, perhaps because they perceive more expensive housing as a hindrance to their well-being.

In a standard life-cycle model, any shock to the total present value of lifetime wealth, such as shocks to the prices of financial securities and housing, translates into a shift in current and future consumption levels. There are two key factors at work. First, real estate is the most important component of wealth. Secondly, housing prices increased at an exceptionally high pace until the break of the financial crisis in 2007. Therefore, estimating the marginal propensity of consumption (MPC) from housing wealth represents a key step in understanding the real effects of wealth changes.

Theoretical predictions on the kinds of asset shocks that ought to generate a strong impact on consumption remain ambiguous (Carroll 2004). On the one hand, a change in house value tends to generate rather illiquid effects, because real estate is usually traded in markets plagued by high frictions and pervasive tax effects while houses are generally non-divisible. On the other hand, housing wealth is widely spread amongst the population and involves not only the highest-income categories, who mainly hold financial assets (typically equities) and have modest MPCs, but also poorer segments, whose consumption and savings behavior are considerably reactive to wealth. Finally, even if one disregards the important role of bequests, house price fluctuations may have no effect on consumption if moving costs are large and the borrowing possibilities for less wealthy, liquidity-constrained agents are limited (Bover 2006; Skinner 1989).

There is quite a large body of empirical literature that has tried to estimate the effects of wealth changes on consumption and savings. At the aggregate level Catte 
et al. (2004) provide an estimate of MPC relative to both housing and financial wealth for OECD countries. Their findings show an MPC rate ranging from 0.05 to 0.08 for Australia, Canada, the Netherlands, the United Kingdom, and the United States, whereas the MPC for Italy, Japan, and Spain is approximately zero, but only marginally significant, and not significant for France and Germany. Interestingly, their estimates of housing wealth effects are larger than financial wealth effects for most of the countries analyzed.

Studies using aggregate data, however, raise serious concerns, mainly due to the lack of relevant controls (Muellbauer 2008) and the risk that spurious relations might affect the estimates. To address these concerns, a number of studies have examined the same issues using panel-like, microeconomic datasets concerning the behavior of individual households with regard to their savings and housing decisions (following Skinner 1996). These datasets, however, rarely contain both measures of consumption/savings and household assets. Disney et al. (2006) use the information contained in the British Household Panel Survey on spending patterns of British households along with countylevel indicators of house prices to estimate the British MPC. They report an MPC for housing wealth shocks of approximately $2 \%$ during the house price boom of the $1990 \mathrm{~s}$. Grant and Peltonen (2008) use the panel section of the Italian Survey of Household Income and Wealth (SHIW) to estimate the impact of changes in housing wealth on nondurable consumption. Their estimated housing wealth effects are small and not significant in general; that is, their MPC is approximately $1 \%$ for homeowners.

A similar study conducted by Guiso et al. (2005) finds that homeowner MPC is about 0.02 cents out of a 1-euro increase in housing capital gains. Sierminska and Takhtamanova (2007) use the first wave of the Luxembourg Wealth Study, an ongoing project conducting cross-country analyses, in their study, which focuses on a sample of homeowners in three countries - Canada (1999), Finland (1998), and Italy (2002) - to estimate the MPC from financial and housing wealth. The authors show the greater influence of housing-related versus financial-related wealth effects. Their findings suggest that for a $1 \%$ increase in housing wealth, households increase their expenditures by about $0.1 \%(0.12 \%$ for Canada, $0.1 \%$ for Finland, and $0.13 \%$ for Italy).

What makes the Italian economy of particular interest is that Italy shares with the United Kingdom the highest ratio of housing wealth to total disposable income, with a value of about 8 (Bartiloro et al. 2008). Muellbauer's (2007) general observation that housing is the most important component of household wealth for OECD countries is then particularly true for Italian households (see also Bertola and Hochguertel 2008).

In this paper we want to assess the effect of a change in the value of real estate assets on optimal consumption and savings behavior in Italian households as a function of household age and composition. We present a simple model, with representative households living for two periods and deriving utility from both housing services and other goods in each period.

Our theoretical model predicts the higher the age of the household and its net estate equity at the beginning of its life, the higher the MPC out of housing wealth. We then test such predictions on the SHIW data, representative of all dwellings owned or rented by Italian households. The dataset contains several features that make it particularly suitable for our research. First, detailed information on household assets, as well as housing, is provided in the dataset. Although appraisals of dwellings are not available, respondents to the SHIW questionnaire, regardless on their ownership status, provide 
subjective evaluations of their dwellings. Second, every household is asked about its outstanding debt on real estate assets. The net value of housing can thus be generated using information available in the data. Finally, the SHIW data provide information on the socioeconomic status (such as age, education, income, and geographical residence) of each household at every cycle. Our results suggest that household consumption for old households is positively and significantly related to household capital gains in housing. On the contrary, for young households (where the household head is less than 40 years) this relation is positive, although only marginally significant. While old households seem to be able to cash in at least a small quota of the net real wealth increase in their real estate portfolio, this is not the case for young households. When house prices increase, the latter are confronted with an expectation of higher future rents. Since the demand for housing services is, to a point, inelastic (and probably increasing), young households anticipate they will have to spend higher amounts for their housing needs and do not cash in the wealth increase induced by higher housing prices.

This paper is organized as follows. Section "The Model" presents the model. Section "Some Stylized Facts About Italian Household Wealth" illustrates some stylized facts on the housing wealth in Italy and Section "The SHIW Dataset" describes the SHIW dataset. Section "Empirical Methodology and Estimation Results" presents the estimation methodology with some preliminary results and Section "Conclusion" concludes. "Appendix A" collects some proofs.

\section{The Model}

Here we outline a very stylized deterministic life-cycle model that closely follows the work of Skinner (1996). As in Skinner's (1996) work and other papers (Buiter 2008; Campbell and Cocco 2007), households derive utility in each period $t$ of their life from the consumption of both housing services $h_{\mathrm{t}}$ and other goods $c_{\mathrm{t}}$. Households live for two periods, discount their future utility at a rate $\delta>0$, and have a time-separable, isoelastic utility function with elasticity $\gamma \in] 0,1[$ :

$$
U\left(c_{t}, c_{t+1}, h_{t}, h_{t+1}\right)=\frac{c_{t}^{1-\gamma}}{1-\gamma}+\mu \frac{h_{t}^{1-\gamma}}{1-\gamma}+\frac{1}{1+\delta}\left(\frac{c_{t+1}^{1-\gamma}}{1-\gamma}+\mu \frac{h_{t+1}^{1-\gamma}}{1-\gamma}\right)
$$

Capital and real estate markets are perfect, so that the interest rate $r$ paid on savings equals the loan rate charged on debt. The price of the non-housing commodity is normalized to one, while the price of the housing service (i.e. the rent per period $t$ ) is denoted by $\rho_{\mathrm{t}}$. At each period of his lifetime the household receives a labour income $Y_{\mathrm{t}}$, and the initial endowment in net housing equity is denoted by $\bar{h}_{t} \geq 0$.

At the end of the first period, each household chooses his optimal level of real estate holdings $h_{t+1}^{*}$, where $h_{t+1}^{*}>\bar{h}_{t}$ indicates an investment in real estate. In the second period households can liquidate $h_{t+1}^{*} \cdot{ }^{1}$ Since in this model markets are

\footnotetext{
${ }^{1}$ This is possible, for example, through a fair "reverse mortgage". Given that there is no bequest motive for households, they will optimally sell the entire $h_{t+1}^{*}$ at the price $P_{t-1}$.
} 
perfect, the amount invested in real estate is irrelevant to the optimal consumption profile. In fact, by a simple no-arbitrage argument, at equilibrium investment in real estate must provide the same return $r$ of the financial investment. Thus the price of one unit of housing equity is equal to the present value of future rents discounted at rate $r$,

$$
P_{t}=\sum_{j=t} \frac{\rho_{j}}{(1+r)^{j-t}}
$$

and the choices of owning a house or renting are equivalent at such prices. Finally, we assume that households know at the beginning of their life cycle all future realizations of the parameters in the budget constraints; we allow only unexpected shocks to hit the housing rents (and hence the house prices).

The intertemporal budget constraint is:

$$
c_{t}+\rho_{t} h_{t}+\frac{c_{t+1}+\rho_{t+1} h_{t+1}}{1+r}=Y_{t}+\rho_{t} \bar{h}_{t}+\frac{Y_{t+1}+\left(\bar{h}_{t}-h_{t+1}^{*}\right) P_{t}+\rho_{t+1} h_{t+1}^{*}}{1+r}+\frac{P_{t+1} h_{t+1}^{*}}{(1+r)^{2}}
$$

where $\left(\bar{h}_{t}-h_{t+1}^{*}\right) P_{t}$ is the revenue the investor obtains from selling part of his initial real estate endowment. Using Eq. 2 we can simplify Eq. 3 as:

$$
c_{t}+\rho_{t} h_{t}+\frac{c_{t+1}+\rho_{t+1} h_{t+1}}{1+r}=Y_{t}+\frac{Y_{t+1}}{1+r}+\rho_{t} \bar{h}_{t}+\frac{P_{t} \bar{h}_{t}}{1+r}
$$

and solve the household maximization problem max (1) in $\left\{c_{\mathrm{t}}, c_{\mathrm{t}+1}, h_{\mathrm{t}}, h_{\mathrm{t}+1}\right\}$ under the constraint (4).

The assumption of isoelastic utility allows us to solve this problem analytically (similarly to Skinner (1996)). The optimal consumption level in the first period is equal to:

$$
c_{t}=\frac{W\left(Y_{t}, Y_{t+1}, P_{t}, \bar{h}_{t}\right)}{K\left(\mu, \gamma, \delta, r, \rho_{t}, \rho_{t+1}\right)}
$$

where $W\left(Y_{t}, Y_{t+1}, P_{t}, \bar{h}_{t}\right)=Y_{t}+\frac{Y_{t+1}}{1+r}+\bar{h}_{t} P_{t}$ is the lifetime wealth of the household and

$$
\begin{aligned}
& K\left(\mu, \gamma, \delta ; r, \rho_{t}, \rho_{t+1}\right) \\
& \quad=\left[1+\rho_{t}\left(\frac{\mu}{\rho_{t}}\right)^{\frac{1}{\gamma}}+\left(\frac{1+r}{1+\delta}\right)^{\frac{1}{\gamma}}(1+r)^{-1}+\left(\frac{1+r}{1+\delta}\right)^{\frac{1}{\gamma}}(1+r)^{-1} \rho_{t+1}\left(\frac{\rho_{t}}{\rho_{t+1}}\right)^{\frac{1}{\gamma}}\left(\frac{\mu}{\rho_{t}}\right)^{\frac{1}{\gamma}}\right]
\end{aligned}
$$

while during the second period optimal consumption is given by:

$$
c_{t+1}=\left(\frac{1+r}{1+\delta}\right)^{\frac{1}{\gamma}} c_{t}
$$

Given the solution (5)-(6) we can quantify the wealth effect of an unexpected (and permanent) increase in house prices (due to increases in future rents) on households' consumption. 
Intuition predicts that, excluding moving costs and bequest motives, the consumption of older generations should be more reactive to shocks in house price. Indeed, old households need fewer future housing services, so that an increase in the value of their houses translates almost entirely into higher net housing wealth. This effect is stronger for households with higher real estate endowments, that is, households that are 'long' in housing equity at the beginning of their lifetime. ${ }^{2}$

The following proposition demonstrates this intuition formally.

Proposition 1 For any value of $\gamma \leq 1$ then $\frac{\partial c_{t}^{o}}{\partial \rho_{t}}>\frac{\partial c_{t}^{y}}{\partial \rho_{t}}$.

The proof is given in "Appendix A".

We now proceed to verify whether this empirical prediction is confirmed by our data.

\section{Some Stylized Facts About Italian Household Wealth}

Wealth is the key variable in shaping household savings and consumption. According to the theory of intertemporal optimization, permanent income is the annuity value of total wealth, comprising financial, real, and human assets. Particularly at later stages in life, wealth, rather than current income, is the crucial variable determining consumption. At this point of time, individuals start living on their wealth and keep their consumption levels constant. Hence, total assets are the key variable to understanding the financial possibilities of households, particularly at later stages of the life cycle.

Italian household net wealth is one of the highest amongst the main OECD countries. In 2005, it was estimated to be equal to an average of 350,000 euros per household and 135,000 euros per capita (Ministry of Finance 2005). Net wealth grew rapidly between 1995 and 2005, by 48\%, equivalent to an average annual real growth rate of $2.7 \%$. This rate of increase was not homogeneous over time, ranging from $5.7 \%$ in 1997 to $0.3 \%$ in 2001 and then increasing again to $4.3 \%$.

An increase in wealth can be generated by either additional savings or capital gains. While their impact was fairly steady throughout 1995-2000, capital gains were almost entirely responsible for the subsequent increase in wealth (D'Alessio et al. 2007). Indeed, over the whole period, from 1995 until 2005, capital gains accounted for $57 \%$ of real wealth growth.

Since housing plays the key role in shaping household assets, we now look at the evolution of housing investments to detect whether housing has driven the wealth increase. Along with (most of the) other OECD countries, Italy has seen a substantial increase in house prices over the last 15 years. The magnitude of the increase has been comparable with that of other European countries, with a real annual increase

\footnotetext{
${ }^{2}$ In reality, moving costs also affect the decision to liquidate a real estate investment (and move or not); thus they may neutralise any real wealth effect due to an increase in house prices for homeowner households (Skinner 1989; Campbell and Cocco 2007). High personal moving costs can then explain why some households do not downsize their net real estate holdings, apparently giving up net real wealth gain. Moreover, as Buiter (2008) points out, it is doubtful that an increase in housing wealth produces an effect on aggregate consumption in a condition of 'housing autarchy' in which 'the inhabitants of a country own the houses they live in' (Buiter 2008, 1). Our partial equilibrium model does not tackle such issues.
} 
of $6.6 \%$ for the time period 2000-2005 (Van den Noord 2006). Despite the fact that housing is the principal component of household wealth, little information can be gathered on house prices and housing wealth in many industrialized countries.

No official estimates are available on Italian house prices at the macro level; however, data are collected on a regular basis by the Ministry of Finance ('Osservatorio del Mercato Immobiliare dell'Agenzia del Territorio') and two private sources (Nomisma and the Consulente Immobiliare). Moreover, the Bank of Italy's SHIW provides subjective house values, that is, as perceived by the respondents. Objective and subjective house prices compare relatively well, as shown in recent work by Cannari and Faiella (2007).

\section{The SHIW Dataset}

We use the SHIW to examine whether housing price appreciation caused an increase in consumption. The Bank of Italy's first SHIW was conducted in 1965. Since then, the survey was conducted yearly until 1987 (except 1985) and every 2 years thereafter. The primary purpose of the SHIW is to collect detailed information on demographics and the socioeconomic behavior of Italian households, as in their consumption, income, and balance sheets.

The SHIW surveys a representative sample of the Italian resident population. Sampling takes place in two stages, first by municipality and then by household. Households are randomly selected from registry office records. The survey covers about 8,000 households, defined as groups of individuals related by blood, marriage, or adoption and sharing the same dwelling. Starting in 1989, each SHIW re-interviewed some households from previous surveys. Respondents included in the panel of the dataset have increased over time: $15 \%$ of the sample was re-interviewed in 1989, $27 \%$ in $1991,43 \%$ in $1993,45 \%$ in $1995,37 \%$ in 1998 , and $48 \%$ in the year 2000 .

The SHIW data are representative of all dwellings owned or rented by Italian households. The dataset has several features that make it particularly suitable for our research, notably the fact that it contains information on both gross and net wealth, with details on its composition, including housing assets and, starting in 1995, outstanding mortgages on real estate assets. As for housing wealth, we use the information given by the respondents on the subjective values of their houses. We calculate the housing net value with the information available in the data. Moreover, given that a core component of the sample is interviewed more than once, we are able to calculate capital gains in real estate for each household. In addition to wealthrelated variables, the dataset contains information on annual household durable and nondurable consumption, thus allowing one to calculate the MPC out of real estate assets. A measure of total financial wealth is also available in the data starting in 1995; however, by itself this does not allow one to distinguish how much of the difference in financial wealth is made up of new savings and how much is made up of capital gains. Information on the socioeconomic status (e.g., age, education, income, and geographical residence) of each household component is asked in each cycle.

Household income is provided in the dataset and is generated as the sum of annual labour and non-labour income (including rents, imputed rents, and net returns on financial assets). 
In order to generate our main sample, we select those households observed at least 2 years in a row. Moreover, we exclude those households that bought their house in the year of the interview, as capital gains calculated on the difference in housing values would be distorted if households changed their dwellings. Since housing wealth, as well as total assets, are recorded at the household level, all individual variables such as education refer to the head of the household. Our final sample covers the years 1995-2004 and is composed of 14,730 households, excluding potential outliers. Table 1 illustrates the descriptive statistics of the sample used for the regression analysis.

\section{Empirical Methodology and Estimation Results}

Our empirical specification has two goals: it aims at (i) estimating whether real estate appreciation enhanced household consumption and (ii) compare the marginal

Table 1 Descriptive statistics

\begin{tabular}{lrc}
\hline Variables & \multicolumn{1}{l}{ Mean } & Standard deviation \\
\hline Consumption & 27852.21 & 19387.93 \\
Financial wealth & 27470.26 & 89782.7 \\
Housing value & 142198.92 & 192185.8 \\
Delta house value *(age $<40)$ & 4403.02 & 40432.64 \\
Delta house value *(age:40-55) & 5695.47 & 58736.37 \\
Delta house value *(age $>55)$ & 8635.09 & 75325.78 \\
Household head's age & 56.98 & 14.53 \\
Age squared & 3458.06 & 1688.02 \\
Employee & 0.31 & 0.45 \\
Self employed & 0.09 & 0.29 \\
Number of household components & 2.82 & 1.30 \\
No spouse in the household & 0.11 & 0.32 \\
Permanent income & 30693.65 & 14318.67 \\
Own housing wealth & 0.72 & 0.45 \\
Council inhabitants: $<20,000$ & 0.28 & 0.45 \\
Council inhabitants: $20,000-40,000$ & 0.21 & 0.40 \\
Council inhabitants: $40,000-500,000$ & 0.43 & 0.49 \\
Council inhabitants: $>500,000$ & 0.07 & 0.26 \\
North & 0.43 & 0.49 \\
South & 0.36 & 0.48 \\
Degree & 0.09 & 0.28 \\
College & 0.28 & 0.45 \\
\hline & & \\
\hline
\end{tabular}

SHIW dataset: Waves 1995-2004. Observations: 14,730. Net housing value has been calculated as total (perceived) housing value less the value of outstanding mortgages at the beginning of the interview year. Household consumption provided in the Survey is calculated as durable and non-durable consumption. Household annual income include all after - tax revenues, without including capital gains 
propensity to consume out of real estate with that of financial asset. Hence we estimate consumption as the annuity value of total wealth, using a standard random effect technique. Accordingly, we estimate the following equation:

$$
C_{h t}=X_{h t}^{\prime} \beta+\alpha Y P_{h t}+\gamma H_{h t}+\phi A_{h t}+\varepsilon_{h t}
$$

where $C_{h t}$, the consumption at time $t$, is a function of socio-demographic variables $(\mathbf{X})$, permanent (labor) income $(Y P)$ and assets: housing $(H)$ and financial asset $(A)$. The subscript $h$ indicates that each variable is measured at household level.

The consumption equation is usually estimated in changes, according to the socalled Euler equation approach (as in Bertola et al. (2005)): this because substantially less information is necessary to estimate consumption changes rather than consumption levels. In fact, consumption changes should depend only on events not predicted by the household, as all predicted changes have been already incorporated into consumption decisions. Our preference would be then for estimating consumption changes as function of changes in wealth. However, as financial capital gains are not observed in our data (where active savings would be confounded with capital gains) we first perform estimates in consumption levels, in order to obtain a MPC on financial versus real estate assets; in a second regression we then focus on changes of consumption on changes of wealth, according to the traditional Euler equation approach.

As explained in the previous section, the consumption variable comprises both durable and nondurable consumption and the cost of services. One of the possible impacts of house price increases could be channeled through rent increases. If rents increase as a consequence of house price increases, consumption could increase merely as a reflection of higher rents, without implying a higher level of wealth for households. A large majority of Italian households (approximately 70\%), however, reside in the house they own and therefore do not have to pay for higher housing services.

A precise test of our predictions focuses on the role played by age on the impact of housing wealth increases on consumption. More specifically, our model predicts that the greater the age at which the (unexpected) price increase materializes, the higher the impact on consumption. Thus, the relation of housing capital gains with the age of the head of the household could shed some light on the different effects that real estate price boosts have on consumption. For this reason, we add a set of interaction terms capturing the impact of housing wealth changes for households whose head is under 40, between 40 and 55, and older than 55 .

Table 2 illustrates our estimation results using consumption levels. We use different specifications to test how real estate assets affect consumption. As we are interested in the overall impact of housing capital gains on consumption, we first run our regressions on the entire sample (column 1) in order to obtain a measure of MPC out of real estate appreciation for the population of Italian households.

Notice that professional status affects consumption in most specifications, the self employed showing a higher consumption at household level. Each additional component in the household increases consumption by approximately 3,000 euros, while a spouse's absence corresponds to lower consumption levels. 
Table 2 Annual household consumption estimates

\begin{tabular}{|c|c|c|}
\hline & Whole sample (1) & Homeowners (2) \\
\hline Financial wealth & $\begin{array}{l}0.013 * * * \\
(0.001)\end{array}$ & $\begin{array}{l}0.008^{* * *} \\
(0.001)\end{array}$ \\
\hline Housing Wealth* (age <40) & $\begin{array}{l}0.022^{* * *} \\
(0.002)\end{array}$ & $\begin{array}{l}0.017 * * * \\
(0.002)\end{array}$ \\
\hline Housing Wealth * (age:40-55) & $\begin{array}{l}0.023^{* * *} \\
(0.001)\end{array}$ & $\begin{array}{l}0.023^{* * *} \\
(0.002)\end{array}$ \\
\hline Housing Wealth* (age >55) & $\begin{array}{l}0.022 * * * \\
(0.001)\end{array}$ & $\begin{array}{l}0.022 * * * \\
(0.001)\end{array}$ \\
\hline Household head's age & $\begin{array}{l}-3.045 \\
(80.515)\end{array}$ & $\begin{array}{l}-141.089^{* *} \\
(66.346)\end{array}$ \\
\hline Household head's age squared $* 10^{-3}$ & $\begin{array}{l}-0.371 \\
(0.693)\end{array}$ & $\begin{array}{l}0.897 \\
(0.568)\end{array}$ \\
\hline Employee & $\begin{array}{l}1657.271^{* * *} \\
(404.931)\end{array}$ & $\begin{array}{l}1708.953 * * * \\
(347.776)\end{array}$ \\
\hline Self-employed & $\begin{array}{l}2250.045^{* * *} \\
(557.952)\end{array}$ & $\begin{array}{l}1219.115^{* *} \\
(490.072)\end{array}$ \\
\hline \# of components & $\begin{array}{l}3574.711 * * * \\
(139.904)\end{array}$ & $\begin{array}{l}3077.712 * * * \\
(114.494)\end{array}$ \\
\hline No spouse in the household & $\begin{array}{l}-1309.654^{* * *} \\
(467.702)\end{array}$ & $\begin{array}{l}-1169.669^{* * *} \\
(381.770)\end{array}$ \\
\hline Permanent income & $\begin{array}{l}0.279 * * * \\
(0.015)\end{array}$ & $\begin{array}{l}0.391 * * * \\
(0.015)\end{array}$ \\
\hline North & $\begin{array}{l}696.054 \\
(447.626)\end{array}$ & $\begin{array}{l}990.720 * * * \\
(358.056)\end{array}$ \\
\hline South & $\begin{array}{l}-5042.610^{* * *} \\
(473.537)\end{array}$ & $\begin{array}{l}-3979.630 * * * \\
(379.280)\end{array}$ \\
\hline Degree & $\begin{array}{l}5592.696^{* * *} \\
(714.651)\end{array}$ & $\begin{array}{l}1107.841^{*} \\
(637.222)\end{array}$ \\
\hline College & $\begin{array}{l}2397.939 * * * \\
(412.616)\end{array}$ & $\begin{array}{l}1011.930^{* * *} \\
(348.759)\end{array}$ \\
\hline Observations & 14730 & 12812 \\
\hline
\end{tabular}

Random effect estimates. Monetary values are expressed in 2005 Ten Thousand Euro. Time dummies and constant are included. SHIW dataset: Waves 1995-2004

Value of standard errors is reported in parentheses: *Significant at 10\%,** significant at $5 \%, * * *$ significant at $1 \%$

As permanent income is one of the main determinants of household consumption, we determine it by using the predicted values of annual household total income (calculated as the sum of labour income and interest income on assets, excluding capital gains) regressed on a set of the head of the household's characteristics (age, gender, and education). Italian households confirm their high propensity to save by consuming approximately $40 \%$ of a 1 -euro increase in permanent income. Finally, 
we find that higher education boosts consumption, with the more highly educated households showing greater annual consumption levels.

Interestingly, the magnitude of the housing wealth coefficient is approximately twice as large as that corresponding to financial wealth, corroborating the macrolevel empirical evidence obtained by Case et al. (2003) and Catte et al. (2004).

Since only homeowners, however, are affected by real estate appreciation, we also present the results for the subsample of homeowners in column (2) of Table 2. The MPC calculated for the subsample of homeowners does not differ from that for the entire sample, confirming that adding renters to the analysis does not change the magnitude of the overall MPC resulting from real estate appreciation (refer again to column (2) of Table 2). When interactive effects are taken into account, we can see that middle-aged households have the highest MPC, equal to $23 \%$, as compared to $17 \%$ for younger households.

We turn then to estimating consumption changes, which is made possible by the panel structure of the data. In doing this we also take into account of a possible drawback of our analysis, concerning the endogeneity of capital gains in housing assets. The observation of capital gains is in fact conditional on being a homeowner, which is not a random variable but, rather, a household choice. Moreover, total consumption and savings and single components of savings in risky assets, such as housing, are driven by the same (unobserved) factors as risk aversion and, generally, different preferences. Neglecting these factors might lead to a bias in the estimation of the impact of housing capital gains on consumption and savings. To address this concern, we jointly estimate the two sets of consumption decisions according to whether or not the household is a homeowner by using an endogenous switching regression technique, with a known regime separator. The two regimes are jointly estimated as follows:

$$
\begin{gathered}
O w n_{h t}^{*}=W_{h t}^{\prime} g+v_{h t} \\
\Delta C_{h t}^{\text {owner }}=\Delta X_{h t}^{\prime} \beta^{O}+\alpha^{O} \Delta Y P_{h t}+\gamma^{O} \Delta H_{h t}+\phi^{O} \Delta A_{h t}+\varepsilon_{h t} \\
\Delta C_{h t}^{\text {renters }}=\Delta X_{h t}^{\prime} \beta^{R}+\alpha^{R} \Delta Y P_{h t}+\gamma^{R} \Delta P_{t}+\phi^{R} \Delta A_{h t}+\varepsilon_{h t 2}
\end{gathered}
$$

where $\mathbf{W}$ contains a set of socio-demographic variables at household and community level. The error terms $\varepsilon_{1}, \varepsilon_{2}$ and $\nu$ are normally distributed with variance $\sigma_{1}, \sigma_{1}$ and 1 respectively, and $\operatorname{Corr}\left[\varepsilon_{1}, v\right]=\rho_{1 v}, \operatorname{Cor}\left[\varepsilon_{2}, v\right]=\rho_{2 v}$. Upper-scripts $O$ and $R$ indicates the parameters corresponding to owners and renters, respectively.

As we want to focus now on the impact of capital gain on consumption evolution, we estimate the consumption equations in changes.

Each household's contribution to the likelihood function is as follows:

$$
\begin{aligned}
\ln L_{h t} & =O w n *\left(\ln \left(\Phi \frac{\left(W^{\prime} g+\rho_{1 v}\left(\varepsilon_{h t 1}\right) / \sigma_{1}\right)}{\sqrt{1-\rho_{1 v}^{2}}}\right)+\ln \left(\phi\left(\left(\varepsilon_{h t 1}\right) / \sigma_{1}\right)\right)\right)+ \\
& +(1-O w n) *\left(\ln \left(1-\Phi \frac{\left(W^{\prime} g+\rho_{2 v}\left(\varepsilon_{h t 2}\right) / \sigma_{2}\right)}{\sqrt{1-\rho_{2 v}^{2}}}\right)+\ln \left(\phi\left(\left(\varepsilon_{h t 2}\right) / \sigma_{1}\right)\right)\right)
\end{aligned}
$$


and we maximize the following likelihood function, consisting of the sum of each contribution:

$$
\ln L=\sum_{h t=1, \ldots, H T} \ln L_{h t}
$$

where $H T$ is the total household-year observations.

Capital gains affect household consumption conditional on owning estate assets; therefore a change in house price only affects consumption through capital gains for homeowners. Changes in house price, however, also affect the savings/consumption decisions of non-homeowners (i.e., renters) through the cost of rent. If house prices increase, the cost of housing services will increase as well, forcing renters to face higher future costs for housing services and thus lowering their overall consumption.

For this reason, we include the change in house price in the consumption change equation-variable $P$ in Eq. $10 .^{3}$

Conversely, if a house price increase is considered a transitory shock, renters should react by instantly increasing their expenditures to face current higher housing costs. The empirical results guide us in distinguishing between the two cases.

Table 3 shows the estimation results for owners and renters in columns 1 and 2, respectively, and the determinants of the regime shifter (house owning) in column 3 . In order to facilitate model identification, we use a set of dummy variables relative to the dimension of the city of residence. These variables are likely to affect the housing supply, and hence the owning decision, but have no influence on the overall amount of consumption. Taking into account the endogeneity of real asset ownership does not substantially change the results.

We concentrate our discussion on the coefficients associated to housing capital gains on consumption. The coefficient for the impact for housing capital gains on consumption is similar in magnitude to those of Table 2. However, when consumption is estimated in changes the coefficient of capital gains is more pronounced for older cohorts who increase their consumption by approximately $€ 26$ when they face an increase in housing price by $€ 1,000$, compared to middle aged households increasing their consumption by only $€ 11$.

Turning to the renter equations (column 2 in Table 3), our estimates suggest that price increase did not affect overall consumption changes with the exception of the older cohorts, who, somewhat unexpectedly, increase their consumption by $€ 2$ when they face a rent increase of $€ 1$.

\section{Conclusions}

In this paper we quantify the MPC out of the financial and nonfinancial assets for Italian households. According to Skinner (1996) and Carroll (2004), recent capital

\footnotetext{
${ }^{3}$ Consumption is linearly dependent on permanent income, as suggested by Eq. 5 . Accordingly, we prefer to estimate consumption in absolute changes. Moreover, estimating consumption in log changes yields poor results, as shown by Carroll (2001).
} 
Table 3 Delta consumption estimates with endogenous primary house wealth

\begin{tabular}{|c|c|c|c|c|}
\hline & Whole sample (1) & $\begin{array}{l}\text { Owners' } \\
\text { consumption (2) }\end{array}$ & $\begin{array}{l}\text { Non owners } \\
\text { consumption (3) }\end{array}$ & $\begin{array}{l}\text { Probability of } \\
\text { owning (4) }\end{array}$ \\
\hline Delta house value $*($ age $<40)$ & $\begin{array}{l}0.017 * * * \\
(0.005)\end{array}$ & $\begin{array}{l}0.019 * * * \\
(0.006)\end{array}$ & & \\
\hline Delta house value $*($ age: $40-55)$ & $\begin{array}{l}0.011 * * \\
(0.005)\end{array}$ & $\begin{array}{l}0.011 * * \\
(0.005)\end{array}$ & & \\
\hline Delta house value $*($ age $>55)$ & $\begin{array}{l}0.026 * * * \\
(0.004)\end{array}$ & $\begin{array}{l}0.024 * * * \\
(0.004)\end{array}$ & & \\
\hline Household head's age & $\begin{array}{l}294.478 \\
(324.366)\end{array}$ & $\begin{array}{l}-27.038 \\
(419.805)\end{array}$ & $\begin{array}{l}1181.809 * * \\
(581.976)\end{array}$ & $\begin{array}{l}0.004 \\
(0.023)\end{array}$ \\
\hline Household head's age squared & $\begin{array}{l}-3.786 \\
(3.408)\end{array}$ & $\begin{array}{l}-0.653 \\
(4.434)\end{array}$ & $\begin{array}{l}-11.639 * \\
(6.110)\end{array}$ & $\begin{array}{l}0.0003 \\
(0.000)\end{array}$ \\
\hline Employee & $\begin{array}{l}-291.722 \\
(645.769)\end{array}$ & $\begin{array}{l}-54.004 \\
(794.564)\end{array}$ & $\begin{array}{l}-1119.927 \\
(798.828)\end{array}$ & $\begin{array}{l}-0.190 * * * \\
(0.045)\end{array}$ \\
\hline Self-employed & $\begin{array}{l}1707.149 \\
(1270.430)\end{array}$ & $\begin{array}{l}2236.597 \\
(1688.298)\end{array}$ & $\begin{array}{l}1554.166 \\
(1302.238)\end{array}$ & $\begin{array}{l}0.374 * * * \\
(0.087)\end{array}$ \\
\hline \# of components & $\begin{array}{l}2730.932 * * * \\
(339.594)\end{array}$ & $\begin{array}{l}2861.489 * * * \\
(425.038)\end{array}$ & $\begin{array}{l}1993.041 * * * \\
(434.120)\end{array}$ & $\begin{array}{l}0.074 * * * \\
(0.014)\end{array}$ \\
\hline No spouse in the household & $\begin{array}{l}492.980 \\
(825.597)\end{array}$ & $\begin{array}{l}452.484 \\
(1146.271)\end{array}$ & $\begin{array}{l}605.000 \\
(1353.069)\end{array}$ & $\begin{array}{l}-0.126^{* *} \\
(0.050)\end{array}$ \\
\hline Permanent income & $\begin{array}{l}0.073 \\
(0.065)\end{array}$ & $\begin{array}{l}0.102 \\
(0.081)\end{array}$ & $\begin{array}{l}0.103 \\
(84.643)\end{array}$ & $\begin{array}{l}0.023 * * * \\
(0.005)\end{array}$ \\
\hline North & $\begin{array}{l}-1498.540 * * * \\
(360.773)\end{array}$ & $\begin{array}{l}-1699.778 * * * \\
(433.545)\end{array}$ & $\begin{array}{l}-644.181 \\
(684.355)\end{array}$ & $\begin{array}{l}-0.128 * * * \\
(0.042)\end{array}$ \\
\hline South & $\begin{array}{l}-999.359 * * * \\
(351.463)\end{array}$ & $\begin{array}{l}-1220.390 * * * \\
(431.427)\end{array}$ & $\begin{array}{l}108.100 \\
(692.342)\end{array}$ & $\begin{array}{l}0.013 \\
(0.046)\end{array}$ \\
\hline Degree & $\begin{array}{l}-481.635 \\
(671.808)\end{array}$ & $\begin{array}{l}-874.888 \\
(785.360)\end{array}$ & $\begin{array}{l}97.968 \\
(1025.246)\end{array}$ & $\begin{array}{l}0.221 * * \\
(0.090)\end{array}$ \\
\hline College & $\begin{array}{l}86.367 \\
(297.618)\end{array}$ & $\begin{array}{l}5.990 \\
(373.191)\end{array}$ & $\begin{array}{l}141.960 \\
(548.976)\end{array}$ & $\begin{array}{l}0.173 * * * \\
(0.045)\end{array}$ \\
\hline Price $*($ age $<40)$ & & & $\begin{array}{l}0.590 \\
(0.452)\end{array}$ & \\
\hline Price *(age:40-55) & & & $\begin{array}{l}0.249 \\
(0.459)\end{array}$ & \\
\hline Price $*($ age $>55)$ & & & $\begin{array}{l}2.448 * * * \\
(0.599)\end{array}$ & \\
\hline House Price* $10^{-3}$ & & & & $\begin{array}{l}0.000214 * * * \\
(0.000)\end{array}$ \\
\hline $\begin{array}{l}\text { Council inhabitants: } \\
20,000-40,000\end{array}$ & & & & $\begin{array}{l}-0.288 * * * \\
(0.046)\end{array}$ \\
\hline $\begin{array}{l}\text { Council inhabitants: } \\
40,000-500,000\end{array}$ & & & & $\begin{array}{l}-0.382 * * * \\
(0.040)\end{array}$ \\
\hline Council inhabitants: $>500,000$ & & & & $-0.635 * * *$ \\
\hline
\end{tabular}


Table 3 (continued)

\begin{tabular}{llll} 
Whole sample (1) & $\begin{array}{l}\text { Owners' } \\
\text { consumption (2) }\end{array}$ & $\begin{array}{l}\text { Non owners } \\
\text { consumption (3) }\end{array}$ & $\begin{array}{l}\text { Probability of } \\
\text { owning (4) }\end{array}$ \\
\hline
\end{tabular}

$\begin{array}{llll}\text { Observations } & 5916 & 2416 & 8132\end{array}$

SHIW wave 1995-2004. Columns 2 to 4 refer to the switch model estimates. Standard errors in parenthesis, clustered at family level. Time dummies are included

The other $\sigma_{1}: 10.235 * * * \sigma_{2},: 9.030 * * * \rho_{1}, 0.67 * * * \rho_{2}$. -0.03 Log likelihood: 67,460

*Significant at $10 \%,{ }^{* *}$ significant at $5 \% ; * * *$ significant at $1 \%$

gains due to the increases in house price may have translated into additional consumption. Our main objective is to assess the magnitude of this effect, if any, and relate it to exogenous household characteristics.

For this purpose, we present a simple life-cycle model where the representative household lives for two periods and consumes housing services and a bundle of other goods.

Using the SHIW data, we estimate annual household consumption to be dependent on variations in house price and financial wealth. In line with the empirical predictions of our model, we find that older households have the highest propensity to consume their real estate capital gains, since they suffer less from the factor driving the increase, that is, higher future rents. The MPC out of (perceived) real estate asset, however, does not significantly differ across age categories. Moreover, our results confirm those of Case et al. (2003) by suggesting that consumption is more reactive to real wealth appreciation than to financial wealth, with an MPC almost twice that of financial assets. We also take into account the fact that benefiting from capital gains on real estate is conditional on owning housing wealth, a decision driven by attitude towards risk, which, in turn, is responsible for deciding the amount to invest in a risky asset and the overall amounts of savings and consumption. Jointly estimating the two decisions does not substantially change the results.

We finally turn to estimate the different impacts of house price changes on renter and homeowner consumption. Considering the endogeneity of homeownership does not change our results for homeowners, confirming an MPC out of real estate capital gains between 1 and 2 cents.

Acknowledgments We gratefully acknowledge the Observatoire de l'Epargne Européenne (OEE) and the Italian ministry of Education for financial support. We acknowledge an anonymous referee and the editor Erasmo Giambona for their valuable comments. Moreover, we want to acknowledge Danny BenShahar, Giovanni Mastrobuoni, Fabio Milani and Massimo Guidolin for their suggestions, as well as the participants to the 12th Conference on Macroeconomic Analysis and International Finance in Rethymno (University of Crete), the Amsterdam-Cambridge-UNC Charlotte Symposium on Real Estate Risk Management (2008), the annual CeRP Conference 2008, and the ICEEE 2009 Conference at University of Ancona. Finally, we are grateful to Emilia Soldani for her excellent research assistance.

Open Access This article is distributed under the terms of the Creative Commons Attribution Noncommercial License which permits any noncommercial use, distribution, and reproduction in any medium, provided the original author(s) and source are credited. 


\section{Appendix}

Proof of Proposition 1 Consider a young household born at time $t$, and assume $\rho_{\mathrm{t}}$ (or, equivalently by $(2), P_{\mathrm{t}}$ ) has unexpectedly increased at the beginning of period $t$ :

$$
\begin{gathered}
\frac{\partial c_{t}^{y}}{\partial P_{t}}=\frac{\partial\left(\frac{W}{K}\right)}{\partial P_{t}}=\frac{\bar{h} K-\frac{\partial K}{\partial P_{t}} W}{K^{2}}=\frac{\bar{h} K-\frac{\partial K}{\partial \rho_{t}} W}{K^{2}} \\
=\underbrace{}_{\text {wealth effect on the net hous. wealth } \quad-\quad \underbrace{\frac{\bar{h}}{\partial \rho_{t}} \frac{W}{K^{2}}}_{\text {lower consumption due to higher rent }}} \\
\frac{\partial K}{\partial \rho_{t}}=0 \text { by envelope theorem } \\
\Rightarrow \frac{\partial c_{t}^{y}}{\partial \rho_{t}}=\frac{\bar{h}}{K}
\end{gathered}
$$

Let us analyze the change in consumption $c_{t}^{o}$ of a household belonging to generation $t-1$ to a change of $\rho_{\mathrm{t}}$. Notice that household $t-1$ has already consumed the (optimal) amounts $c_{t-1}^{y}$ in its first life period, hence the total (real and financial) wealth at the beginning of period $t$ (i.e. at the moment the shock on $\rho_{\mathrm{t}}$ occurs), is fixed. This amounts to say that

$$
c_{t}^{o}+\rho_{t} h_{t}^{o}=Y_{t}+A_{t-1}(1+r)+\bar{h}\left(\rho_{t}+\frac{P_{t+1}}{1+r}\right)
$$

where $A_{t-1}$ is the financial wealth of the household invested in period $t-1$. Given that $h_{t}^{o}=\left(\frac{\mu}{\rho_{t}}\right)^{1 / \gamma} c_{t}^{o}$ at optimum, we have:

$$
c_{t}^{o}=\frac{Y_{t}+A_{t-1}(1+r)+\bar{h} P_{t}}{1+\rho_{t}\left(\frac{\mu}{\rho_{t}}\right)^{1 / \gamma}}
$$

and

$$
\begin{gathered}
\frac{\partial c_{t}^{o}}{\partial P_{t}}=\frac{\partial c_{t}^{o}}{\partial \rho_{t}}=\underbrace{\frac{\bar{h}}{1+\rho_{t}\left(\frac{\mu}{\rho_{t}}\right)^{1 / \gamma}}}_{\text {wealth effect }}-\underbrace{\frac{Y_{t}+A_{t-1}(1+r)+\bar{h}\left(\rho_{t}+\frac{P_{t+1}}{1+r}\right) \partial\left(1+\rho_{t}\left(\frac{\mu}{\rho_{t}}\right)^{1 / \gamma}\right)}{\partial \rho_{t}}}_{\text {change in consumption due to higher rent }} \\
\frac{\partial\left(1+\rho_{t}\left(\frac{\mu}{\rho_{t}}\right)^{1 / \gamma}\right)^{2}}{\left.\partial \rho_{t}\left(\frac{\mu}{\rho_{t}}\right)^{1 / \gamma}\right)}=\left(\frac{\mu}{\rho_{t}}\right)^{1 / \gamma}\left(1-\frac{1}{\gamma}\right) \text { negative for } \gamma<1
\end{gathered}
$$

A sufficient condition for $\frac{\partial c_{t}^{o}}{\partial \rho_{t}}>\frac{\partial c_{t}^{y}}{\partial \rho_{t}}$ is then $\gamma \leq 1$, since in this range of $\gamma$ also $\frac{\bar{h}}{K}<\frac{\bar{h}}{1+\rho_{t}\left(\frac{\mu}{\rho_{t}}\right)^{1 / r}}$. 
We compute here the effect of a change in the risk-free rate $r$ at time $t$ on the consumption of the young and of the old generation respectively.

$$
\begin{aligned}
\frac{\partial c_{t}^{y}}{\partial r} & =\frac{\partial\left(\frac{W}{K}\right)}{\partial \rho_{t}}=\frac{\frac{\partial W}{\partial r} K-\frac{\partial K}{\partial r} W}{K^{2}}=\underbrace{\frac{-\frac{1}{(1+r)^{2}}\left(Y_{t+1}+\bar{h} P_{t+1}\right)}{K}}_{\text {wealth effect }}-\underbrace{\frac{\partial K}{\partial r} W}_{\text {substitution effect }} \\
\frac{\partial K}{\partial r} & =\left(1+\rho_{t+1}\left(\frac{\rho_{t}}{\rho_{t+1}}\right)^{1 / \gamma}\left(\frac{\mu}{\rho_{t}}\right)^{1 / \gamma}\right)\left(\left(\frac{1+r}{1+\delta}\right)^{(1 / \gamma)-1} \frac{1}{\gamma(1+\delta)(1+r)}-\left(\frac{1+r}{1+\delta}\right)^{1 / \gamma} \frac{1}{(1+r)^{2}}\right) \\
& =\left(1+\rho_{t+1}\left(\frac{\rho_{t}}{\rho_{t+1}}\right)^{1 / \gamma}\left(\frac{\mu}{\rho_{t}}\right)^{1 / \gamma}\right)\left(\frac{1+r}{1+\delta}\right)^{(1 / \gamma)-1} \frac{1}{(1+\delta)(1+r)}\left(\frac{1}{\gamma}-1\right)
\end{aligned}
$$

where the wealth effect is negative: hence, if the substitution effect is not too negative (i.e. if $\gamma$ is sufficiently low), $\frac{\partial c_{t}^{v}}{\partial r}<0$.

For the older cohort living at time $t$ :

$$
\frac{\partial c_{t}^{o}}{\partial r}=\frac{\partial\left(\frac{W^{o}}{1+\rho_{t}\left(\frac{\mu}{\rho_{t}}\right)^{1 / \gamma}}\right)}{\partial r}
$$

where $W^{o}=Y_{t}+A_{t-1}(1+r)+\bar{h}\left(\rho_{t}+\frac{P_{t+1}}{1+r}\right)$ is the total of resources available at the beginning of period $t$ to generation $t-1$. Assuming for simplicity that all future rents are constant and equal to $\rho$ we obtain:

$$
\frac{\partial c_{t}^{o}}{\partial r}=\frac{1}{1+\rho_{t}\left(\frac{\mu}{\rho_{t}}\right)^{1 / \gamma}} \frac{\partial W^{o}}{\partial r}=\frac{1}{1+\rho_{t}\left(\frac{\mu}{\rho_{t}}\right)^{1 / \gamma}}\left(A_{t-1}-\bar{h} \frac{\rho}{1+r}\right)
$$

which is for sure negative for net borrowers (i.e. $A_{t-1}<0$ ) and when $\bar{h}$ is large enough. Only net savers $\left(A_{t-1}>0\right)$ who do not own an initial endowment in real estate increase their non-housing consumption when the interest rate increases. The wealth effect on real estate equity is negative, thus of opposite sign as the wealth effect on financial savings.

\section{References}

Bartiloro, L., Coletta, M., \& De Bonis, R. (2008). Italian household wealth in a cross-country perspective. Bank of Italy Temi di Discussione, Working Paper, No. A2.

Bertola, G., \& Hochguertel, S. (2008). Household debt and credit: Economic issues and data problems. Economic Notes, 36, 115-146.

Bertola, G., Guiso, L., \& Pistaferri, L. (2005). Uncertainty and consumer durable adjustment. Review of Economic Studies, 72(4), 973-1007. doi:10.1111/0034-6527.00358.

Bover, O. (2006). Wealth effects on consumption: Microeconometric estimates from a new survey of household finance. CEPR Discussion Paper Series No. 5847.

Buiter, W. H. (2008). Housing wealth isn't wealth. NBER Working Paper Series, No. 14204.

Campbell, J. Y., \& Cocco, J. F. (2007). How do house prices affect consumption? Evidence from micro data. Journal of Monetary Economics, 54, 591-621. doi:10.1016/j.jmoneco.2005.10.016.

Cannari, L., \&Faiella, I. (2007). House prices and housing wealth in Italy. Bank of Italy, Mimeo. 
Carroll, C. (2001). Death to the log-linearized consumption euler equation! (and very poor health to the second-order approximation). Advances Macroeconomics, 1(1). Article 6.

Carroll, C. D. (2004). Housing wealth and consumption expenditure. Mimeo: Johns Hopkins University.

Case, K. E., Quigley, J. M., \& Shiller, R. J. (2003). Comparing wealth effects: the stock market versus the housing market. Journal of Economic Perspectives, 17(1), 1-32.

Catte, P., Girouard, N., Price, R., \& André, C. (2004). Housing markets, wealth and the business cycle. OECD Working Paper No. 17.

D’Alessio, G., Faiella, I., Gambacorta, R., \& Iezzi, S. (2007). Household wealth in Italy 1995-2005. Mimeo: Bank of Italy.

Disney, R., Bridges, S., \& Gatherhood, J. (2006). Housing wealth and household indebtedness: is there a household 'financial accelerator'?. Nottingham, Mimeo: University of Nottingham.

Grant, C., \& Peltonen, T. A. (2008). Housing and equity wealth effects of Italian households. ECB Working Paper Series No. 857.

Guiso, L., Paiella, M., \& Visco, I. (2005). Do capital gains affect consumption? Estimates of wealth effects from Italian households' behavior. Bank of Italy, Working Paper, No. 555.

Ministry of Finance. (2005). Il patrimonio dello Stato Informazioni e Statistiche.

Muellbauer, J. (2007). Housing and personal wealth in a global context. WIDER Research paper, 2007/27.

Muellbauer, J. (2008). Housing, credit and consumer expenditure .CEPR Discussion Paper No. 6782.

Skinner, J. (1989). Housing wealth and aggregate saving. Regional Science and Urban Economics, 19(2), 305-324. doi:10.1016/0166-0462(89)90008-2.

Skinner, J. (1996). Is housing wealth a sideshow? In D. Wise (Ed.), Advances in the economics of aging, pp. 241-268. Chicago: University of Chicago Press.

Sierminska, E., \& Takhtamanova, Y. (2007). Wealth effects out of financial and housing wealth: Cross country and age group comparison. Federal Reserve Bank of San Francisco, Working Paper Series, 2007-01.

Van den Noord, P. (2006). Are house prices nearing a peak? A probit analysis for 17 OECD countries. OECD Economics Department Working Paper, No. 488. 